\title{
MUATAN PORNOGRAFI ANAK PADA LINGKARAN PEDOFILIA DI DUNIA MAYA
}

\author{
Astri Yogatama \\ Program Studi Ilmu Komunikasi, Universitas Kristen Petra Surabaya \\ Email: astri@petra.ac.id
}

\begin{abstract}
Child exploitation by online paedophile is all over the world. Image, chat and audio-visual child pornography is exchange in the ring of online paedophile. Certain countries have developed strong cyberlaw to attack the presence of this dangerous cyber communities. Cyber Law still needs precise definition of child pornography content, specially in cyberworld. The definition must cover image, chat, audiovisual, writing of a child, in the sexual conduct and pseudo-pothograph.
\end{abstract}

Keywords: Child Pornography Content, Paedophile.

\section{PENDAHULUAN}

Wonderland Club adalah nama sebuah weblog berbayar. Weblog ini berisi komunikasi para e-pedofilia untuk saling bertukar file bermuatan (content) porno dimana anak-anak menjadi obyek persepsi seksual. Persepsi seksual ditujukan pada situasi dimana para pengunjung menikmati visualisasi berupa foto (image) dan percakapan (posting message, chatting) tentang anak-anak dalam pose sensual (menampilkan hubungan sex atau anggota tubuh secara terbuka dengan penonjolan bagian tertentu) maupun natural (beraktivitas harian, misalnya tertawa, bermain). Kenikmatan yang dipersepsikan, kemudian menjadi pendorong bagi pengunjung website untuk melakukan tindakan (konasi) lanjutan berupa mengunduh file, berkomentar, melakukan kegiatan seks maupun mengunggah file koleksi pribadi. Weblog adalah "pages of short, frequently updated postings by an individual that are arranged chronologically, much like a series of diary entries or journal pages. Blogs can contain thoughts, links to sites o internets, rants, or whatever the blogger wants to write about"(Pavlik, 2004, p. 297).

Pada tahun 1998 polisi Inggris bekerjasama dengan Amerika, Jerman, Italia, Norwegia, Finlandia, Belgia, Austria, Perancis, Swedia, dan Portugis menggelar operasi "Chatedral" untuk melacak jalur komunikasi para e-pedofilia yang walaupun berkumpul dalam "ring" pedofilia, keberadaan fisik mereka tersebar di beberapa Negara. Hasilnya adalah 11 orang tertangkap berasal dari Inggris, 32 dari Amerika, 18 dari Jerman, 16 dari Italia, dan 8 orang dari Negara sisanya. Sebagai "efek samping", para pelaku e-pedofilia belajar dari pengalaman dan menggunakan identitas"anonymous" untuk bergerilya di dunia maya dan mengelabui polisi.

Pedofilia merupakan jenis kejahatan terhadap anak yang sudah lama terjadi di masyarakat. Melalui pengertian "an adult who is sexually attracted to a child or 
children" (Government, 2007;1), pedofilia bukan hanya sebuah perbuatan (behavior), namun juga merupakan sikap (attitude) yang menyimpang. Sehingga tendensi suka pada anak-anak demi kepuasan seksual dari seorang dewasa, dapat dikategorikan sebagai pedofilia. Masalah e-pedofilia menjadi semakin serius dengan berkembang pesatnya teknologi dunia maya atau internet. Kemampuan masyarakat baik secara financial maupun teknologi informasi, selain membawa kemajuan di bidang akademis, juga membuka peluang bagi masyarakat yang menyimpang seperti pedofilia. Hasil penelitian di Inggris, sepanjang tahun 1994-1998 telah terjaring 400 orang yang terbukti mengambil gambar porno anak dana 529 orang yang terbukti memiliki gambar porno anak untuk memperdagangkannya di internet maupun memilikinya sebagai koleksi pribadi. Pada sebuah negara dimana teknologi informasi seperti internet telah menjadi perangkat sehari-hari, penanganan perbuatan kriminal dunia maya dianggap sama seriusnya dengan kriminalitas di dunia nyata. Pedofilia online sangat berkaitan dengan yang disebut sebagai pornografi anak, dimana artinya "a permanent record of a child's sexual assault that exploits the victim each time it is viewed for pleasure" (Ferraro, 2005;5). Pedofilia online mengeksploitasi anak melalui gambar anak berbau "seksual" di internet.

Salah satu korban e-pedofilia menceritakan kisahnya pada konggres Amerika, bernama Mariya Nikolaevna Yashenkova yang lahir pada tanggal 25 Agustus 1992 di Rusia sebagai anak dari keluarga yang berantakan. Mariya diangkat anak oleh Mancuso, seorang warga Negara Amerika separuh baya yang kemudian kerap menyebut Mariya sebagai Masha. Sejak pertama kali mengangkat Masha, Mancuso telah merencanakan perbuatan kriminalnya sebagai seorang pedofilia kelas berat. Masha diperlakukan sangat buruk sebagai obyek seksual secara fisik dan gambar perbuatan porno Mancuso terhadapnya di-upload Mancuso pada website pribadi Mancuso yang dapat diakses oleh e-pedofilia lainnya. Hal tersebut berlaku selama 5 tahun hingga polisi federal dapat mengendus perbuatan Mancuso dan memenjarakannya berdasarkan hukum perlindungan anak atas perbuatan yang tidak senonoh di internet. Polisi federal memperoleh jejak Mancuso melalui teknologi "tracking" di internet.

Kasus lainnya pada tahun 2005 beberapa weblog yang dikelola oleh blogger Indonesia memuat gambar panas seorang gadis SMA yang di duga sebagai "Yuk Mojokerto 2005”. Persebaran gambar sangat cepat dan mungkin ratusan orang sudah pernah mengakses gambar yang menghebohkan tersebut. Berapa kasus lain juga telah melibatkan banyak "anak"sebagi obyek seksual online. Browser Google bila diberikan kata kunci "bispak anak sd" dan ditemukan frase sebanyak 215.000, "gambar seks sd" sebanyak 1.570.000, "foto bugil anak smp" sebanyak 440.000 (akses 24 Januari 2011) yang tersebar di berbagai alamat web. Artinya adalah Indonesia pun tidak terbebas dari para "predator" sebagai istilah lain dari pelaku e-pedofilia yang megunggah/mengunduh gambar porno anak-anak. Weblog ini diantara berbayar maupun gratis. Selain gambar, terdapat pula grup diskusi, chatting, dan mailing list tempat para pedofilia bertukar cerita.

Urgensi pembahasan e-pedofilia tidak berhenti pada tahun 2001 ketika Wonderland dihentikan beredar di dunia maya. Internet Watch Foundation (IWF), sebuah organisasi nirlaba di United Kingdom (UK), yang berfokus dalam pencegahan kejahatan pada anak melalui internet mencatat bahwa kejahatan dalam cyberworld tidak berhenti. IWF membuka hotline laporan dari masyarakat Inggris Raya tentang 
situs yang memuat gambar maupun tulisan yang menampilkan pornografi anak. Tercatat pada tahun 2010, 48.702 laporan pengunjung internet tentang situs bermuatan pornografi anak. Jumlah laporan ini meningkat $27,6 \%$ diibandingkan tahun 2009 (http://www.iwf.org.uk). Analis internet melakukan penelusuran ke situs asal dan mengklasifikasikan temuan seperti data Tabel 1.

Tabel 1. Klasifikasi Situs Bermuatan Pornografi Anak berdasarkan Laporan Pengunjung Internet di Inggris tahun 2010 kepada IWF

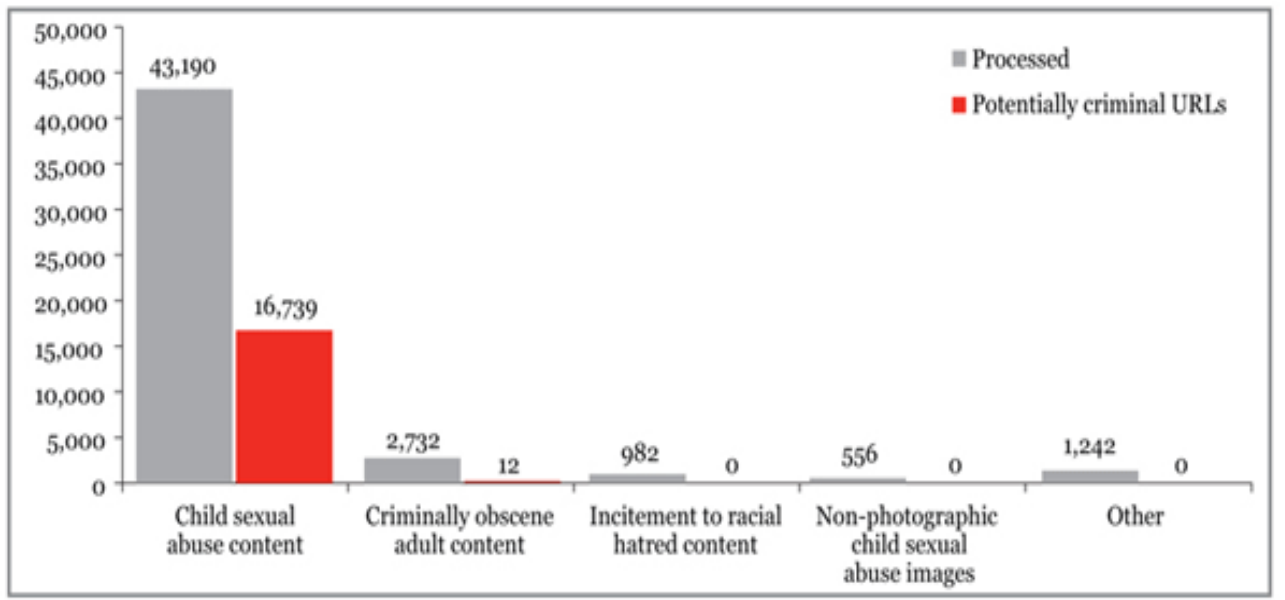

Sumber: www.iwf.org.uk

Hasil reportase Koran kompas.com edisi Agustus 2010 dalam judul "Alamak, Sepertiga Situs Negatif Buatan Indonesia", mengungkapkan bahwa "Badan Pengurus Nasional Asosiasi Warnet Indonesia (AWARI) menyatakan, Domain Number System (DNS) Nawala saat ini telah memblokir sekitar 1 juta situs negatif di internet. Dari jumlah tersebut, sepertiganya ternyata situs buatan Indonesia" (http://tekno.kompas.com/read/2010/08/12/08533388/Alamak.Sepertiga.Situs.Negatif.u atan. Indonesia). Pornografi dunia maya terjadi dalam area internasional maupun nasional dan terus akan meningkat seiring dengan kemudahan akses dunia maya. Salah satu cara mengatasi peredaran muatan pornografi anak adalah melalui regulasi maya (cyber regulation). Penyusunan regulasi untuk muatan di dunia maya berproses dan berawal dengan merujuk pada regulasi pidana hukum konvensional, untuk menentukan definisi muatan pornografi anak di internet. Definisi muatan akan menjadi dasar bagi pengkategorian sebuah imaji, termasuk pornografi biasa atau pornografi anak. Selanjutnya definisi dapat menjelaskan tingkah laku pelaku (pengunduh, pengunggah, penyimpan, perekayasa, penikmat) pornografi anak di internet, manakala mereka termasuk berperilaku menyimpang tertentu (pedofilia).

Berbagai negara telah mendefinisikan secara jelas konsep pornografi anak. Sementara itu di Indonesia, dalam undang-undang anti pornografi no. 44 tahun 2008 istilah pornografi anak tidak dijabarkan secara khusus dalam bagian tertentu. Upaya penetapan konsep muatan pornografi anak akan lebih menegaskan kepedulian atas perlindungan anak, terutama karena komunikasi kejahatan di dunia maya. 


\section{DEFINISI MUATAN PORNOGRAFI ANAK}

Dalam upaya menjaring para e-pedofilia, polisi federal Inggris menggunakan beberapa dasar. Dalam salah satu perundangan termaktub "Protection of Children Act 1978, the offence in section 1 of the 1978 states, it is an offense for a person (a) to take, or permit to be taken or to make, any indecent photographs or pseudophotograph of a child, (b) to distribute or show such indecent photograph or pseudophotographs" (Akdeniz, 2001). Pseudo-photograph adalah sebuah gambar, baik yang dihasilkan melalui komputer grafis atau lainnya yang ditampilkan sebagai sebuah foto. Foto menurut Criminal Justice and Public Order Act 1994 adalah data yang disimpan dalam disc atau atau alat elektronik lainnya yang dapat dikonversi menjadi sebuah foto. Landasan lain yang pernah dipergunakan oleh polisi federal Inggris adalah aturan di Section 160 of the Criminal Justice Act 1988 yang berisi,

"(1) It is an offense for a person to have any indecent photograph or pseudophotograph of a child in his possession, (2) It is an offense for a person to have any indecent photograph or pseudo-photograph of a child in his possession, (3) Where a person is charged with an offense under (1) above, it shall be a defense for him to prove that he had a legitimate reason for having the photograph or pseudo-photograph in his possession; or he had not himself seen the photograph or pseudo-photograph and did not know, nor had any cause to suspect, it to be indecent; or the photograph or pseudo-photograph was sent to him without any prior request made by him or on his behalf and that he did not keep it for an unreasonable time" (Akdeniz, 2001).

Di Inggris adalah suatu pelanggaran bagi seseorang untuk memiliki foto tidak senonoh atau pseudo-photograph dari seorang anak di tangannya. Pseudo photograph adalah imaji yang dimanipulasi dengan teknik gambar digital maupun manual. "Pseudo-photographs are technically photographs, but they are created by a variety of ways including by computers by the use of photo/image software. For example,a child's face can be superimposed on an adult body or to another child's body together with the alteration of the characteristics of the body. A pseudo-photograph can also be created by taping together two photographs and then making a photocopy of that taped photograph. The photograph on the photocopy could be regarded as a pseudophotograph. Pseudo-photographs and images can also be created entirely by software without using any real images." (Akdeniz, 2008;21). Dalam pseudo-photograph maupun foto asli dari seorang anak, tema sentral yang membuat imaji tersebut menjadi pilihan e-pedofilia adalah muatan porno atau erotis yang merangsang keinginan seksual terhadap anak. Memiliki foto anak yang dimanipulasi untuk perbincangan seksual, dikategorikan sikap menyukai hubungan seks dengan anak. Pendapat ini menguatkan argumentasi bahwa pemiliki imaji bermuatan pornografi anak dapat dikategorikan sebagai e-pedofilia dan dapat dihukum sebagai pelaku pedofilia. "This argument has also been raised in the United States and it is suggested by the findings of a US Senate Committee that paedophiles use any form of child pornography to stimulate and whet their own sexual appetites. Policy makers intend to control and criminalize the market for such materials regardless of how such content may be created “(Akdeniz, 2008;23) 
Di Negara Inggris atau Amerika, memiliki foto asli maupun yang sudah dimodifikasi/dimanipulasi dengan pose telanjang dalam jumlah tertentu dalam kurun waktu tertentu (koleksi) adalah dapat dikategorikan sebagai pelaku pedofilia. Sedangkan visualisasi muatan pornografi pada anak menurut undang-undang federal Amerika no.1466A adalah,

"a visual depiction of any kind, including a drawing, cartoon, sculpture, or painting, photograph, film, or computer-generated image or picture, whether made or produced by electronic, mechanical, or other means, of sexually explicit conduct, where it (1) depicts a minor engaging in sexually explicit conduct and is obsence, or (2) depicts an image that is, or appears to be, of a minor engaging in graphic bestially, sadistic or masochistic abuse or sexual intercourse, including genital-genital, oral-genital, anal-genital, or oral-anal, whether between persons of the same or opposite sex, and such depiction lacks serious literary, artistic, political, or scientific value. Sexually explicit conduct includes various forms of sexual activity such as intercourse, bestiality, masturbation, sadistic or masochistic abuse and lascivious exhibition of the genitals. It is illegal to possess, distributive or manufacture these image (http://uscode.house.gov/download/ title_18.shtml)

Gambar visual baik itu kartun, patung, lukisan, foto, film yang dihasilkan oleh komputer, dimana nampak perilaku seksual eksplisit/cabul anak di bawah umur yang terlibat dalam tindakan sadis, masokis, hubungan seks, termasuk hubungan genital-genital, oral-genital, anal-genital, atau oral-anal, baik antara orang-orang dari penggambaran yang sama atau berlawanan jenis kelamin, dan seperti tidak memiliki nilai sastra, seni, politik, atau ilmiah yang serius dan pameran bernafsu dari alat kelamin, dikategorikan tindakan ilegal.

Memutuskan muatan pornografi anak dalam ring e-pedofilia tidak mudah, sebab foto anak tidak seluruhnya bercerita tentang perbuatan sex. Foto anak dalam aktivitas sehari-hari misalnya bayi tidur, seorang gadis tertawa riang, dapat menjadi obyek favorit dalam ring e-pedofilia online. "For example, it is argued that consumers tend to dislike child pornography that portrays child sex as distressing or painful for the child victim (Taylor and Quayle, 2003). Imagery that suggests that the child is actually enjoying his or her victimisation may be their preference (Taylor and Quayle, 2003) "(Howwit, 2007, p.8). Gambar anak dalam pose tidak berdosa, dapat menjadi obyek fantasi seksual kaum pedofilia. Regulasi di Inggris dan Kanada, memasukan unsur gambar "innocent" dalam kategori pornografi anak, jika terletak dalam konteks perbincangan seksual,

"There are jurisdictions in which the definition of child pornography is demonstrably more precise than, say, in UK legislation. Section 263 (1) of the Canadian Criminal Code states, according to Mehta (2002, p. 323), that child pornography includes photographic, film, video, and electronic media portrayals of:

1. A person under the age of 18 years engaging in sexual or explicit sexual activity or depictions of them being so engaged.

2. Depictions of predominantly sexual organs or anal areas of a person under the age of 18 years for sexual purposes. 
3. Written or visual representations that 'advocate or counsel' sexual activity involving a person under the age of 18 years are also an offence under the Code"

(Howwit, 2007;17)

Penggalan regulasi di atas, memasukkan unsur "depictions of predominantly sexual organ" dalam konsep pornografi anak, khususnya bagi tujuan seksual. Tujuan seksual memang tidak semata-mata tergambar jelas dalam foto, film, video maupun media elektronik. Tujuan seksual adalah konteks dimana imaji itu bertempat. Dalam ring pedofilia, dimana para predator saling mempercakapkan hasrat seksual terhadap anak-anak dalam foto yang dipertukarkan, membuat foto-foto anak tersebut disebut sebagai foto bermuatan pornografi anak.

Undang-undang anti pornografi di Indonesia no. 44 tahun 2008 pasal 1 menyebutkan konsep pornografi sebagai berikut:

Pornografi adalah gambar, sketsa, ilustrasi, foto, tulisan, suara, bunyi, gambar bergerak, animasi, kartun, percakapan, gerak tubuh, atau bentuk pesan lainnya melalui berbagai bentuk media komunikasi dan/atau pertunjukan di muka umum, yang memuat kecabulan atau eksploitasi seksual yang melanggar norma kesusilaan dalam masyarakat.

Selanjutnya di pasal 4 dikatakan salah satu jenis pornografi adalah pornografi anak. Tidak terdapat konsep yang jelas tentang "kecabulan", "eksploitasi seksual" maupun "pornografi anak". Ketidakjelasan konsep tersebut mempersulit pengkategorian imaji pornografi anak dalam lingkaran e-pedofilia. Belum terdapat konsep muatan pornografi anak dan konteks seksual yang dimaksud dalam komunikasi di dunia maya.

Tindakan kriminal pada anak melalui dunia maya adalah modus operansi kriminal baru sebagai bagian dari perubahan konstruksi sosial dari dunia virtual. Kecenderungan perbuatan kejahatan pada anak melalui internet makin meningkat dari tahun ke tahun. Keberadaan hukum di Inggris dan Amerika telah berusaha mengakomodasi kondisi sosial masyarakatnya yang gelisah akibat ulah para pelaku pedofilia online dan hasilnya masih belum maksimal karena begitu sulitnya menengarai proses transaksi via internet, merujuk pada tersangka yang pasti, serta mengumpulkan bukti-bukti kejahatan "virtual".

\section{REGULASI DUNIA MAYA}

Cyberspace was a consensual hallucination that felt and looked like a physical space but actually was a computer generated construct representing abstract data" (Willian Gibson, "Neuromancer", Ace, New York, 1984). Neuromancer karya Gibson merupakan novel yang mempopulerkan kata "cyberspace" dan konsepnya. Menurut Gibson ada ruang di dalam media "cyber" dan kehidupan maya di dalamnya. Secara ilmiah sebenarnya keberadaan "maya" itu sendiri tidak sepenuhnya maya atau tidak nyata, karena sesungguhnya maya di sini adalah realitas lain yang dibangun oleh komunikasi virtual dari hasil representasi informasi digital 0 dan 1 yang bersifat diskrit. 
Keberadaan cyberspace dimana teori tentang batas suatu wilayah tidak dapat dipergunakan, maka muncul suatu pemikiran untuk merekonstruksi definisi tentang masyarakat dunia maya, termasuk aturan yang menjamin penyelenggaraan proses interaksi maya. Namun muncul persoalan dari sana, dimana tidak semua "penghuni" dunia maya setuju dengan model aturan konvensional:

1. Kelompok pertama secara total menolak setiap usaha untuk membuat aturan hukum bagi aktivitas-aktivitas di Internet yang didasarkan pada sistem hukum tradisional. Dengan pendirian seperti ini, maka menurut kelompok ini internet harus diatur sepenuhnya oleh sistem baru yang didasarkan atas norma-norma hukum yang baru pula yang dianggap sesuai dengan karateristik yang melekat pada internet. Kelemahan utama kelompok ini adalah mereka menafikan fakta, meskipun aktivitas internet itu sepenuhnya beroperasi secara virtual, tetapi masih tetap melibatkan masyarakat (manusia) yang hidup di dunia nyata.

2. Kelompok kedua berpendapat bahwa penerapan sistem hukum tradisional untuk mengatur aktivitas-aktivitas di internet sangat mendesak untuk dilakukan. Perkembangan internet sangat mendesak untuk dilakukan. Perkembangan internet dan kejahatan yang melingkupi begitu cepat sehingga yang paling mungkin untuk pencegahan dan penanggulangannya adalah dengan mengaplikasikan sistem hukum tradisional yang saat ini berlaku. Kelemahan utama kelompok ini merupakan kebalikan dari kelompok pertama, yaitu mereka menafikan fakta bahwa aktivitas-aktivtas di internet menyajikan realitas dan persoalan baru yang merupakan fenomena khas masyarakat informatika yang sepenuhnya dapat direspon oleh sistem hukum tradisional.

3. Kelompok ketiga tampaknya merupakan sintesis dari kedua kelompok di atas. Mereka berpendapat bahwa aturan hukum yang akan mengatur mengenai aktivitas di Internet harus dibentuk secara evolutif dengan cara menerapkan prinsip-prinsip common law yang dilakukan secara hati-hati dan dengan menitikberatkan kepada aspek-aspek tertentu dalam aktivitas cyberspace yang menyebabkan kekhasan dalam transaksi-transaksi di Internet. Kelompok ini memiliki pendirian yang cukup moderat dan realistis karena memang ada beberapa prinsip hukum tradisional yang masih dapat merespon persoalan hukum yang timbul dari aktivitas internet di samping juga fakta bahwa beberapa transaksi di internet tidak dapat sepenuhnya direspon oleh sistem hukum tradisional.

4. Kelompok keempat adalah kelompok yang sama sekali menolak adanya regulasi di cyberspace. Penolakan ini didasarkan pada asumsi bahwa cyberspace adalah ruang yang bebas dan pemerintah pun tidak berhak untuk melarang sesuatu tindakan apapun di cyberspace itu. Landasan utama dari kelompok ini adalah Declaration of Independence of Cyberspace dari John Perry Barlow dan Hacker Manifesto dari Loyd Blankenship (the Mentor). (Prastiono, 2009:20)

Perdebatan di atas merupakan gambaran umum perdebatan Internasional terhadap keberadaan regulasi di dunia maya. Pemerintah Negara Inggris dan Amerika lebih cenderung untuk memilih pendapat kelompok ketiga dengan memadukan aturan tradisional dan baru. Pada kasus pemberantasan ring group "Wonderland", pemerintah Inggris menggunakan hukum "Protectition of Children Act 
1978", namun karena istilah "photograph" pada tahun 1978 belum mencakup aspek virtual maka definisi "photograph" pun didefinisikan ulang.

Salah satu tantangan penegakkan hukum dunia maya adalah perbedaan konsep batas wilayah Negara riil dan Negara "virtual". Lebih lanjut Middleton dalam kutipan Edmon Makarim menuliskan kompleksitas penerapan yurisdiksi di internet, adalah antara lain karena "The internet further complicates the application of these complexes territoriality based jurisdictional principles because:

1. Material posted on the internet has a worldwide audience

2. There is an enormous and growing number of internet users internationality

3. It is easy to move a website from one jurisdiction to another

4. A website can be hosted in one jurisdiction, but directed at users in another jurisdiction

5. Parts of a website may be hosted in one jurisdiction, while other parts of the website are hosted in another jurisdiction, and

6. It is not always possible to determine where a website or a users is located.

(Makarim, 2004;494)

Keberadaan data dan pengelolanya di internet tidak mengenal wilayah yang sama, menyebabkan terjadinya kesulitan hukum secara tegas mengacu pada ketentuan negara tertentu saja.

Penanganan kejahatan online semakin rumit jika melibatkan warga Negara asing. Amerika dalam hal ini telah mengantisipasinya melalui pemberlakuan Long Arm Statute, dimana diberlakukannya hukum bagi orang asing yang berada atau berhubungan dengan orang Amerika secara legal dan mempengaruhi Amerika. Hukum ini telah menyeret dua orang Indonesia, Jenice Reedy dan Thomas Reedy dalam kasus penyelenggaraan pornografi anak di bawah umur melalui internet di Amerika (Mudjiarjo, "Menyeret Pemilik Situs Porno Berdasarkan Perjanjian Kerja"). Kemudian kasus "Wonderland" telah menunjukkan bagaimana kesepakatan antar Negara dalam operasi "Catheral" merupakan salah satu upaya mengatasi ricuhnya penentuan wilayah "virtual".

\section{REGULASI DUNIA MAYA DI INDONESIA}

Usaha preventif dan konstruktif dalam pengaturan dunia maya bukan hal yang mengada-ada. Kejahatan dunia maya (cyber crime) semakin hari semakin bervariasi, berlomba-lomba dengan hukum yang diterapkan. Cybercrime sangat berhubungan erat dengan computer crime yang didefinisikan "perbuatan atau tindakan yang dilakukan dengan menggunakan komputer sebagai alat/sarana untuk melakukan tindak pidana atau komputer itu sendiri sebagai objek tindak pidana. Kemudian, secara sempit kejahatan komputer itu adalah satu perbuatan melawan hukum yang dilakukan dengan teknologi komputer yang canggih” (Makarim, 2005;427-428)

Cybercrime hanya dapat diatasi dengan menggunakan cyberlaw, hukum yang dapat dipergunakan untuk mengatasi kejahatan via internet. Secara umum cyberlaw mencakup e-commerce, domain name, copyright, defamation, content regulation, dan international issues. Kajian hukum dunia maya di Indonesia dimasukkan dalam kajian Hukum Telematika, dimana aspek teknik dan non-teknis regulasi dunia maya dipelajari. Fokus kajian Hukum Telematika meliputi: 
1. Keberadaan komponen-komponen dalam sistem tersebut, yakni mencakup : (i) perangkat keras, (ii) perangkat lunak; (iii) prosedur-prosedur: (iv) perangkat manusia; dan (v) informasi itu sendiri; dan

2. Keberadaan fungsi-fubgsi teknologi di dalamnya, yakni: (i) input; (ii) proses; (iii) output; (iv) penyimpanan dan; (v) komunikasi.

(Makarim, 2005: 10-11)

Dalam cyberspace, fokus kajian Hukum Telematika dalam juga digolongkan menjadi 4C yaitu content (isi), computing (proses), communication (komunikasi), dan community (masyarakat). Makarim dalam mengkaji Hukum Telematika, terlebih dahulu mempelajari secara khusus dan mendalam isi hukum formal tradisional dan menemukan bahwa beberapa pasal dapat dipergunakan untuk membahas masalah Telematika yang terjadi kini:

1. Undang-Undang no.39 tahun 1999 tentang Hak Asasi Manusia

Garis besar UU adalah jaminan akan hak asasi manusia seperti termaktub dalam Hak Asasi Manusia yang diterbitkan oleh PBB, termasuk hak privasi atas milik pribadi. UU ini dapat dipakai untuk menjerat para "pencuri" barang pribadi, termasuk para e-pedofilia yang gemar mengambil gambar tak senonoh anak-anak dan memamerkannya bahwa melakukan e-commerce di Internet. Namun kemudian muncul masalah untuk informasi yang tidak "dicuri", namun diberikan secara sukarela oleh individu kepada sebuah website di Internet. Misalnya pada transaksi e-commerce selalu akan ditanyakan perihal identitas pembeli barang. Identitas tersebut ter-upload secara virtual di Internet dan hingga saat ini hukum Indonesia belum dapat melindungi data pribadi yang semacam ini dari usahausaha tidak bertanggungjawab yang dapat terjadi di internet. Tantangan lainnya adalah masalah pembuktian kejahatan online yang masih belum diatur secara jelas di Indonesia, dimana bukti tranksaksi online di Internet belum diakui sebagai barang bukti di pengadilan.

2. UU no.40 tahun 1999 tentang Pers

UU Pers berisi kaidah menjalankan fungsi Pers yang bermoral, termasuk larangan menayangkan informasi yang amoral/porno. Media porno dapat terjerat oleh UU ini, namun di sisi lain informasi porno tidak hanya di-upload oleh insane pers, siapa saja dapat memasukkan informasi porno di internet.

Pada tahun 2010, Kementrian Komunikasi dan Informasi menerbitkan kerangka hukum telekomunikasi yang merupakan turunan dari pasal 28F UUD RI 1945 seperti pada Tabhel 2 .

Diantara ke-empat regulasi telekomunikasi, Undang Undang Nomor 11 Tahun 2008 Tentang Informasi dan Transaksi Elektronik adalah satu-satunya regulasi yang menyertakan muatan elektronik yang dilarang. Istilah porno dalam dunia maya tidak tertuliskan secara jelas, hanya tersirat sebagai tindakan "asusila".

Dari perspetkif fokus kajian Hukum Telematika content (isi), computing (proses), communication (komunikasi), dan community (masyarakat) atau disebut dengan 4C, muatan pornografi anak dapat dikategorikan dalam content (isi).

Tabel 2. Kerangka Hukum Telekomunikasi Indonesia 


\section{Pasal 28F UUD RI 1945}

"Setiap orang berhak untuk berkomunikasi dan memperoleh informasi untuk mengembangkan pribadi dan lingkungan sosialnya, serta berhak untuk mencari, memperoleh, memiliki, menyimpan, mengolah, dan menyampaikan informasi dengan menggunakan segala jenis saluran yang tersedia."

Undang Undang Nomor Undang Undang Nomor 32 Undang Undang Nomor 11 Undang Undang Nomor 14

36 Tahun 1999 Tentang Tahun 2002 Tentang

Telekomunikasi Penyiaran
Tahun 2008 Tentang

Informasi dan Transaksi Elektronik
Tahun 2008 tentang

Keterbukaan Informasi Publik
Muatan Regulasi:

1. Penyelenggara Telekomunikasi

2. Larangan Praktek Monopoli

3. Perijinan

4. Interkoneksi dan biaya hak penyelenggaraan

5. Perangkat Telekomunikasi

6. Spektrum Frekuensi Radio

7. Orbit Satelit
Muatan Regulasi:

1. Penyelenggaraan Penyiaran

2. Komisi Penyiaran Indonesia

3. Jasa Penyiaran

4. Lembaga Penyiaran

5. Stasiun Penyiaran dan Wilayah Jangkauan Siaran

6. Perijinan

Penyelenggaraan Penyiaran

7. Pelaksanaan Penyiaran 7. Penyidikan

8. Peranserta Masyarakat 8. Ketentuan Pidana

2. Penyelenggaraan Sistem Elektronik

Masyarakat
Muatan Regulasi: $\quad$ Muatan Regulasi:

1. Informasi, dokumen, dan 1. Hak dan Kewajiban tanda tangan elektronik pemohon dan pengguna Sertifikasi Elektronik \&

3. Nama Domain, Hak

Kekayaan Intelektual, dan Perlindungan Hak Pribadi. 4. Perbuatan yang Dilarang 5. Penyelesaian Sengketa 6. Peran pemerintah dan informasi public serta hak dan kewajiban badan public

2. Informasi yang wajib disediakan dan diumumkan

3. Informasi yang dikecualikan

4. Mekanisme memperoleh informasi

5. Komisi Informasi keberatan dan penyelesaian sengketa melalui komisi informasi

6. Hukum Acara Komisi

7. Gugatan ke Pengadilan dan Kasasi

8. Ketentuan Pidana

(Kominfo, 2010;70)

\section{KESIMPULAN \& REKOMENDASI}

\section{Kesimpulan}

Konsep muatan pornografi anak harus dapat melingkupi definisi pornografi anak dan konteks imaji dimana foto anak dikomunikasikan. Hal ini dilakukan untuk memperjelas jenis kejahatan yang terjadi, sehingga dapat diberikan rekomendasi rehabilitasi kejahatan maupun penanganan korban kejahatan dengan tepat. Pornografi anak meliputi imaji/perbincangan tentang anak yang bermuatan hubungan seks maupun imaji anak yang diperbincangan dalam konteks hubungan seks dengan orang dewasa.

Hukum dunia maya (cyber law) harus dapat bersinergi dengan hukum konvensional untuk dapat mengarahkan definisi content dalam fokus hukum telematika di Indonesia, agar kejahatan pornografi anak di dunia maya dapat dikenali dengan tepat, untuk tindakan hukum selanjutnya.

\section{Rekomendasi}

Indonesia memerlukan hukum lokal yang berlaku untuk pelanggaran dunia maya yang berasal dari Negara lain, mengingat karakteristik website yang berbeda dengan dunia nyata. Hukum tersebut harus dapat mengakomodir perlindungan anak secara luas dan futurist, artinya berlaku hingga di kemudian hari (contoh hukum Protection of Children Act 1978 dari Inggris) 
Tidaklah mencukupi untuk mengandalkan hukum dalam dunia nyata untuk mengatasi kejahatan terhadap anak-anak di internet. Karena kejahatan seperti epedofilia adalah kejahatan yang mayoritas bukan bermotifkan ekonomi, namun lebih pada kejahatan karena konsep moralitas yang keliru.

Usaha sensor sebagai kontrol dimana terjadi "control over media, refers to the act of prohibiting certain expression or content” (Pavlik, 2004;462). Amerika memang sangat menentang keras "censhorship"karena asas kebebasan pers yangmereka anut pada amandemen pertama "Congress shall make no law respecting an establishing of religion, or prohibiting the free exercise thereof; or abridging the freedom of speech, or the press; or the right of the people peaceably to assemble and to petition the Government for a redress of grievences"(Goodwin, 1983;5). Namun karena mereka juga menganut asas hukum material, maka amademen pertama diperkecualikan untuk kegiatan sensor media di sekolah-sekolah dalam rangka melindungi moral bangsa. Dalam hal ini usaha sensor dilakukan oleh pemerintah atau badan pengawas internet. Diharapkan lembaga semacam ini juga hadir di Indonesia, tentunya dengan kemampuan professional yang memadai.

Amerika juga memberikan perkecualian kepada perpustakaan Universitas untuk meng-upload informasi porno sebagai bagian dari riset akademik semata. Namun perkecualian ini pun dikompensasikan dengan biaya registrasi yang tidak murah kepada pemerintah. Sensor yang terjadi di Indonesia masih belum berlandaskan kriteria yang jelas, sehingga sangat subyektif dan sarat unsur politis kekuasaan. Untuk itu perlu adanya kejelasan kriteria sensor isi media internet di masa depan.

\section{DAFTAR RERERENSI}

Akdeniz, Yaman, 2001, Regulation of Child Pornography on the Internet, http;//www. cyber-rights.org/reports/ukcases.htm.

,2008, Internet child pornography and the law: national and international responses, Ashgate.

Ferraro, Monique, Mattei, 2005, Investigating Child Exploitation and Pornography: The Internet, The Law and Forensic Science, Elsevier Academic Press.

Goodwin, H.Eugene, 1983, Grouping for Ethic in Journalism, Iowa State University Press.

Government, Australian, 2007, Paedophiles and Onlien Grooming, NetAlert.

Howwit, Sheldon, 2007, Sex Offenders and the Internet, John Wiley and Sons Kementrian Komunikasi dan Informasi, 2010, Komunikasi dan Informatika Indonesia Whitepaper 2010.

Makarim, Edmon, 2004, Kompilasi Hukum Telematika, PT. Raja Grafindo Persada.

Makarim, Edmon, 2005, Pengantar Hukum Telematika, PT. RajaGrafindo Persada.

Pavlik, John, Vernon, 2004, Converging Media: an Introduction to Mass Communication, Allyn \& Bacon.

Prastiono, Idha, Endri, 2009, Peran POLRI dalam Penanggulangan Kejahatan Hacking terhadap Bank, Sekolah Pascasarjana Universitas Sumatera Utara. 
States, United, 2011, US Code, (http://uscode.house.gov/download/title_18. html).

Thurlow, Crispin \& Team, 2004, Computer Mediated Communication: Social Interaction and The Internet, Sage Publication.

Wahyono, Teguh, 2006, Etika Komputer dan Tanggungjawab Profesional di Bidang Teknologi Informasi, CV Andi Offset. 